\title{
The implementation of progressive mathematization model as means to enhance understanding and communication ability of junior high school student
}

\author{
Klara Iswara Sukmawati \\ Program Studi Pendidikan Matematika, Sekolah Tinggi Keguruan dan Ilmu Pendidikan Surya. Jalan \\ Imam Bonjol No. 88, Bojong Jaya, Karawaci, Tangerang, Indonesia. \\ E-mail: klaraiswara.sukmawati@stkipsurya.ac.id \\ Received: 3 October 2017; Revised: 20 November 2017; Accepted: 20December 2017
}

\begin{abstract}
The study was based on the importance of students' mathematical understanding and communication ability. The students still need some efforts in attaining mathematical understanding and communication ability. As a result, the researcher sense that they should design Progressive Mathematization Model in order to enhance the mathematical understanding and communication ability of the students especially the junior high school ones. Then, in conducting the study the main purpose was analysing the enhancement of mathematical understanding and communication ability of the students. The study was a quantitative research. The population in this study was the seventh-grade students of SMPN 1 Pagedangan and the sample in this study consisted of two groups that had been selected by means of purposive sampling. The researcher implemented four test instruments of mathematical understanding and communication ability within the study. The data that had been gathered would be analysed by means of independent $t$-test. The findings of the study showed that the enhancement of mathematical understanding and communication ability of the students on the progressive mathematization model had been better than the enhancement of mathematical understanding and communication ability of the students on conventional learning.

Keywords: progressive mathematization model, mathematical understanding ability, mathematical communication ability

How to Cite: Sukmawati, K. (2018). The implementation of progressive mathematization model as a mean to enhance understanding and communication ability of junior high school students. Jurnal Riset Pendidikan Matematika, 5(1), 30-42. doi:http://dx.doi.org/10.21831/jrpm.v5i1.16056
\end{abstract}

Permalink/DOI: http://dx.doi.org/10.21831/jrpm.v5i1.16056

\section{INTRODUCTION}

Education is a key of success for any individual. With education, an individual may view the world, pursue aspirations, and manifest dreams. In relation to the significant role of education, Indonesia has been improving the educational system as an effort of raising the educational quality. One of the improvements that have been pursued shifting the 2006 Educational Unit-Level Curriculum into the 2013 Curriculum. The 2013 Curriculum suggests the standards of graduate competences that contain multiple capabilities that students should master after attending the learning process; these capabilities refer to the aspects of attitude (spiritual and social), the aspects of knowledge, and the aspects of skills. In order to support the achievement of these competencies, in 2013 Curriculum there are several changes that emphasize more scientific approach within the learning process.

Scientific approach contains five steps in a learning process namely observing, inquiring, gathering information, reasoning, and communicating. Communicating, as having been implied, is the last step in this approach. It is apparent that communication is important to be possessed by the students in order that they may actively participate in the learning process with such scientific approach and the same significance also applies in the learning process of Mathematics. Therefore, the students' mathematical communication capability is necessary. The mathematical communication capability refers to the capability of designing model, 


\section{Jurnal Riset Pendidikan Matematika, 5 (1), 2018 - 31}

Klara Iswara Sukmawati

defining arguments, composing ideas/answers in own language, and composing questions regarding Mathematics.

In line with the above explanation Ontario Ministry of Education (2005) also states that mathematical communication is an essential process within the learning process of Mathematics because through the communication students contemplate, clarify, and expand their ideas and understanding with regards to mathematical arguments and relationships. Baroody \& Coslick (1993) also explains the important reasons why the learning process should be focused on the communication; in his opinion he said that mathematics is essentially a language and that mathematics and mathematics learning are, at heart, social activities. In addition, the students' communication capability in learning becomes the main standard in the learning process of Mathematics as having been formulated in the Standard National Council of Teachers of Mathematics (National Council of Teachers of Mathematics, 2000). Students are expected to possess the capabilities to explain ideas/initiatives/solutions regarding the mathematical problems within the learning process. Thereby, the learning process may run more optimally.

In relation to the importance of having communication capability among the students, Pugalee (2001) states that students should be habituated to provide arguments for each answer and to provide responses upon the answer that the other students provide so that the learning process will be more meaningful. The indicators of mathematical communication capability that will be applied in this study are namely: associating actual objects, figures, and diagrams to the mathematical ideas; expressing, demonstrating, and illustrating ideas that have been possess visually with different manners; stating daily events in the form of mathematical language or symbol; explaining ideas, situations, and relations in Mathematics by using actual object, figure, diagram, graphic, and algebra representation; and analysing, evaluating, and composing statements toward given information.

In order to support the achievement of good communication capability, there should be quite good understanding. As having been stated by Albert Einstein (Einstein, n.d.), if you can't explain if simply you don't understand it well enough. In other words, the communication capability of an individual is strongly correlated to the understanding that the individual has.
Herawati, Siroj, \& Basir (2010) also states that concept understanding is the most important part within the learning process of Mathematics. The reason is that Mathematics does not only about memo-rizing both mathematical concepts and following problem-solving procedures/steps but also demands relationship and association to more simpler facts (Idris, 2009).

Based on the theoretical review that has been conducted, the indicators of mathematical understanding that will be applied in the study are as follows: discovering the understanding o a concept in own language; identifying mathematical concept that a problem contains; discerning one concept from another in Mathematics; explaining inter-concept relationship in problem-solving activities; and turning one form of representation to another.

Understanding capability is demanded in order to support the students' communication capability. The researcher has found an association between the two capabilities which are important for the students to master. In order to develop both capabilities, there should be an effort to make sure that the students have good communication and understanding capability. Within the effort of assisting the students to have good mathematical and understanding capability, there should be a teaching method/ manner that is considered able to answer such challenge. Several studies that have been conducted, in relation to the case, are the ones by Subagiana (2009), Anggraeni (2013), and Hendriana (2012). In this study, the researcher will implement a learning method to increase the students' communication and understanding capability.

One of the learning models that might be developed and might be selected as reference for the teachers is the tiered mathematization (Susento, 2007). This learning model is developed by integrating several approaches namely contextual approach, problem-based learning approach, cooperative approach, conventional approach, and realistic-education approach (Rudhito, 2005). The modelling in the realistic approach is categorized into the "model of" and the "model for" (Gravemeijer, 1994). The "model of" refers to the description of the given situation, while the "model for" refers to the abstract model of the given situation. This abstract model is one of the forms of horizontal mathematization (Treffers, 1993). This model may also serve as a means for the new didactical principles namely: (1) performing guided 
reinvention process in Mathematics learning activities; (2) looking for the contextual problems that serve as the starting point in the learning process; and (3) empowering cooperative classroom within the learning management in the classroom. The learning activities in this learning model consist of several tiers in enactive activities, iconic activities, symbolic activities, and formal activities.

In relation to the activity tiers, in the enactive activities the students are provided contextual problem-solving activities that involve the body movement (physical actions) and the concrete objects. Then, in the iconic activities are provided with contextual problemsolving description and activities that involve figure models and the figure models might be in the form of schemes or situation descriptions. Next, in the symbolic activities the students are expected to be able to describe and to solve contextual problems by using symbols, terms, or independently discovered procedures that display their reasoning skills. Last but not the least, in the formal activities the students should solve mathematical problems that involve the use of terms, symbols, and standard procedures in the Formal Mathematics.

In the tiered mathematization model, the teachers should begin the learning process by performing contextual problem-solving activities and should gradually enter Formal Mathematics tiers (Susento \& Rudhito, 2008). The learning process should start from the objects that the students recognize and then expand to the shadows of the concrete objects, the use of symbols, and eventually the abstract tiers. Winayawati, Waluya, \& Junaedi (2012) propose that a new mathematical concept will be easily understood by an individual if, in learning the new concept, the individual has established associations to the concepts that he or she has previously studied.

The learning activities in a mathematical topic is a process of tiered mathematization that consists of enactive activity tiers, iconic activity tiers, symbolic activity tiers, and formal activity tiers. The ladder of tiered mathematization model might be viewed in Figure 1:

Through the use of this ladder, it is expected that Mathematics will be more meaningful and encourage the students to attain better understanding toward the learning materials that the teachers provide so that the students will have better comprehension capacity. Using contextual problems as the starting point in the learning process is the first didactical principle. In addition to using the contextual problems and the four activity tiers, this model also benefits the cooperative classroom in the implementation. With the presence of the cooperative classroom, the students are expected to have better communication capacity. Using cooperative classroom itself is the second didactical principle.

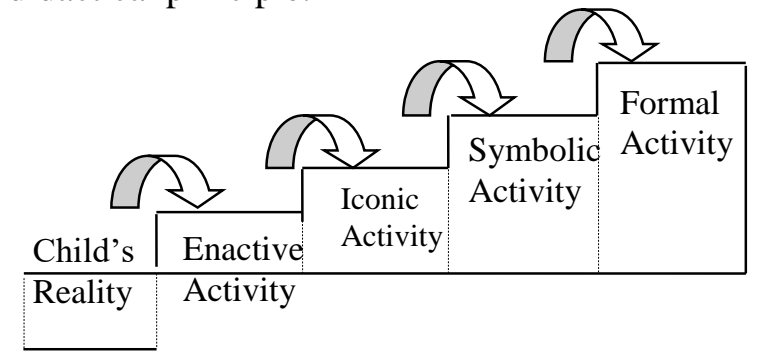

Figure 1. Ladder of Tiered Mathematization Model

The third didactical principle is using guided reinvention during the learning process. Guided reinvention is conducted in order that the students might find a concept as if an inventor finds his or her own concept. In other words, this process might be regarded as a constructivist, interactive, and reflective process. The bottom line is that in performing a learning process the teachers do not directly provide the students with formulas or procedures that should be followed; instead, they should emphasize the mathematical contexts (Nelissen, 1993). From the implementation of the 3 didactical principles in the tiered mathematization model it is expected that the students might improve their mathematical comprehension and communication capacity. Based on these elaborations, the researcher through this study would like to analyse how the improvement of mathematical comprehension and communication capacity between the junior high school students who attend the tiered mathematization model-based learning process and those who attend the conventional learning process. A study that has been conducted with regards to the implementation of this model is the study by Sukmawati $(2010,2014)$ that implements the model on the learning materials of algebra and integers.

\section{METHOD}

The study made use of quantitative approach using quai-experimental study with two equivalent classes. The study was conducted in April 2015 on SMP Negeri 1 Pagedangan, 
Tangerang. The learning process in both classes was conducted within six meetings. In one meeting, the researcher need two learning periods (80 minutes).

The population of this study was the VII Grade students of SMPN 1 Pagedangan. Then, the sample of the study was two classrooms; one classroom served as the experimental group that had been given treatment in the form of tiered mathematization model and the other classroom served as the control group that had been given treatment in the form of conventional learning model. From this point forward, the experimental group was labelled as Tiered Mathematization Model (TMM) group and the control group was labelled as Conventional Mathematization Model (CMM). In assigning the students into the two groups, the sample was randomly selected using the random assignment technique. The reason was that the researcher could not perform random sampling technique because the class had been established and therefore the class could not be changed. Both classes had almost equal characteristics and mathematical capacity level. The mathematical capacity of both classes belonged to the "Low" category.

The study was a quasi-experimental research with two equal classes. The design that the researcher implemented in the study was the pre-test-post-test control group design.

$\begin{array}{cccc}\mathrm{R} & \mathrm{O} & \mathrm{X} & \mathrm{O} \\ \mathrm{R} & \mathrm{O} & - & \mathrm{O}\end{array}$

Note:

$\mathrm{R}$ : Sample selection that was conducted under random assignment

$\mathrm{O}$ : Administration of mathematical comprehension and communication test

$X$ : Learning process by means of tiered mathematization model

The method that was implemented in the study was the quantitative method. The quantitative method was implemented in analysing the students' mathematical comprehension and communication capacity and their improvement. The researcher interpreted the data that had been gathered as the materials and the discourses for the occurring conditions.

The students in the experimental group performed their learning process by implementing the tiered mathematization model, while the students in the control group performed their learning process by implementing the conventional mathematization model. The researcher wanted to gain deeper knowledge on how the learning process had been conducted in the experimental group and how the mathematical comprehension and communication capacity of the students in the experimental group was after attending the tiered mathematization model. In the study, the researcher also reviewed the improvement on the students' mathematical comprehension capacity.

The design that the researcher implemented in this study was the pre-test-post-test control group design. Prior to conducting the learning process, the researcher administered a test in order to see the students' mathematical comprehension and communication capacity before administering the treatment. Then, the researcher administered the treatments to the students in the two different groups. One group was provided with the Tiered Mathematization Model (TMM) and the other group was provided with the Conventional Mathematization Model (CMM). After the treatment administration had been completed, the researcher administered the same test in order to assess how far the students improved their mathematical comprehension and communication.

\section{Data, Instrument, and Data Gathering Technique}

The data for the study were gathered by means of test administration. The test was administered in order to assess how far the students improved their mathematical comprehension and communication capacity after they had been exposed to the Tiered Mathematization Model treatment. The test was conducted two times in the following procedure: a pre-test was conducted before the learning process and a post-test was conducted after the learning process. From the test administration, the researcher attained the data on the students' scores. The test was administered to the students from both groups namely the TMM and the CMM.

The instrument in this study was the test instrument. The test instrument was the test of students' mathematical comprehension and communication capacity that had been developed from the materials that had been taught. The test was able to contain the test items that measured the mathematical comprehension and communication capacity that wad adjusted to the indicators of each capacity. The test instrument was designed in tiered manner and was 
consulted to the academic advisor with competency in the given domain and the teachers of Mathematics in the research site.

Before the test was administered to the subjects, the test had been administered first in terms of face validity and content validity. The test instrument that had been designed were validated by five lecturers who had competency in the given domains and the names of the lecturers were as follows: Al Jupri, Ph.D.; Dr. Stanley Dewanto, M.Pd.; Rully Charitas Indra Prahmana, S.Si, M.Pd.; Bobi Rahman, M.Pd.; and Joseph Hayon, M.Pd. After having been validated, the test instrument was revised in accordance to the given directions. The researcher revised the test design prior to administrating the test to the subjects.

After the test instrument had been validated and been revised, the test instrument was administrated first to the non-subject students (one class) who had studied the learning materials of One Variable Linear Regression. The test was administered on Friday, March $27^{\text {th }} 2015$, from 13:30 until 14:50 on Grade VII-5 SMPN 2 Pagedangan. The test that had been administered consisted of 5 essay items and each essay item consisted of 2 numbers. The researcher administered the test and then the test analysed the test instrument in terms of validity, reliability, discriminative capacity, and difficulty level. In conducting the validity test toward the test items of the test instrument, the researcher implemented the Product Moment Correlation that had been proposed by Pearson. Based on the results of the calculation, the researcher found that the validity of the test instrument belonged to the "Moderate" and the "High" category while the reliability coefficient of the test instrument had been equal to 0.732 which also belonged to the "High" category. The discriminative capacity of the test instrument that had been administered belonged to the "Moderate" and the "High" category. The difficulty level of the test instrument belonged to the "Moderate" category for 6 numbers and to the "Difficult" category for 4 numbers.

\section{Data Analysis Technique}

The quantitative analysis that had been implemented was the manual statistical calculation by means of Microsoft Excel and the calculation by means of SPSS 15 . The data that had been gathered from the test results included the pre-test data, the post-test data, and the $\mathrm{N}$ gain data. The data analysis was preceded by the examination on the students' responses based on the assessment rubric that had been designed and by the calculation on the test score of students' mathematical comprehension and communication capacity. The data that had been gathered from the students in terms of pre-test, post-test, and $\mathrm{N}$-gain were normalized under the following formula:

$g=\frac{S_{\text {pos }}-S_{\text {pre }}}{S M I-S_{\text {pre }}}$

In which:

$S_{\text {pre }}$ : Pre-test Score

$S_{\text {pos }}:$ Post-test Score

$S M I$ : Ideal Maximal Score

Prior to the normalization, the researcher should perform the normality and the homogeneity test; then, the researcher should perform the mean equivalence test using t-test, specifically the Independent Sample t-Test. If the data were normal and were not homogenous then the researcher would perform the t-test. On the other hand, if the data were abnormal then the researcher would perform the nonparametric test specifically the Mann-Whitney test. The results of the test would be able to answer the problem formulations of the study.

\section{RESULTS AND DISCUSSIONS}

From the problem formulations that have been explained previously, the researcher would like to view the improvement on the students' mathematical comprehension and communication capacity both for the students who have been treated by the Tiered Mathematization Model (TMM) and the students who have been treated by the Conventional Mathematization Model (CMM). The quantitative data analysis includes the pre-test data analysis, the post-test data analysis, and the $\mathrm{N}$-gain data analysis on the students' mathematical comprehension and communication capacity.

Both the pre-test and the post-test items that the students had completed were scored based on the assessment rubric that had been designed. The followings were the description on the pre-test score and the post-test score on the students' mathematical comprehension and communication capacity both for the TMM group and the CMM group.

Table 1. The Test Results for the Mathematical Comprehension Capacity 
Jurnal Riset Pendidikan Matematika, 5 (1), 2018 - 35

Klara Iswara Sukmawati

\begin{tabular}{crrrrrr}
\hline \multirow{2}{*}{ Statistical Data } & \multicolumn{3}{c}{ TMM Group } & \multicolumn{3}{c}{ CMM Group } \\
\cline { 2 - 7 } & \multicolumn{1}{c}{ Pre-test } & Post-test & \multicolumn{1}{c}{ N-gain } & \multicolumn{1}{c}{ Pre-test } & Post-test & \multicolumn{1}{c}{ N-gain } \\
\hline $\mathrm{N}$ & 32.00 & 32.00 & 32.00 & 31.00 & 31.00 & 31.000 \\
$\mathrm{x}_{\min }$ & 0.00 & 9.00 & 0.20 & 0.00 & 1.00 & 0.000 \\
$\mathrm{X}_{\max }$ & 6.00 & 21.00 & 0.80 & 5.00 & 15.00 & 0.550 \\
$\bar{x}$ & 2.94 & 14.09 & 0.51 & 2.29 & 7.94 & 0.251 \\
$\mathrm{SD}$ & 1.52 & 3.39 & 0.15 & 1.47 & 4.06 & 0.160 \\
$\%$ & 11.76 & 56.36 & 50.80 & 9.16 & 31.76 & 25.100 \\
\hline
\end{tabular}

Note:

Ideal Maximal Score $=25.00$

$\mathrm{N}$-gain Ideal Score $=1.00$

Pre-test and Post-test Mean Scale ranged from 0 - 25, N-gain Scale ranged from 0 - 1, and Percentage Scale ranged from $0-100$.

From the above results, it is apparent that the mean score of the pre-test in the TMM group is 0.65 higher than that of the pre-test in the CMM group. In terms of score, the percentage of TMM group is $2.60 \%$ higher than that of CMM group. On the other hand, the mean score of the post-test in the TMM group is 6.15 points higher than that of the post-test in the CMM group. The mean score of $\mathrm{N}$-gain between the two groups is separated by 0.26 point. The mean score results in the fact that the percentage of $\mathrm{N}$ gain between the groups is $50.80 \%$ for the TMM group and $25.10 \%$ for the CMM group. The comparison on the mean score of the pre-test, the post-test, and the $\mathrm{N}$-gain in terms of students' mathematical comprehension capacity is presented in Figure 2 as follows.

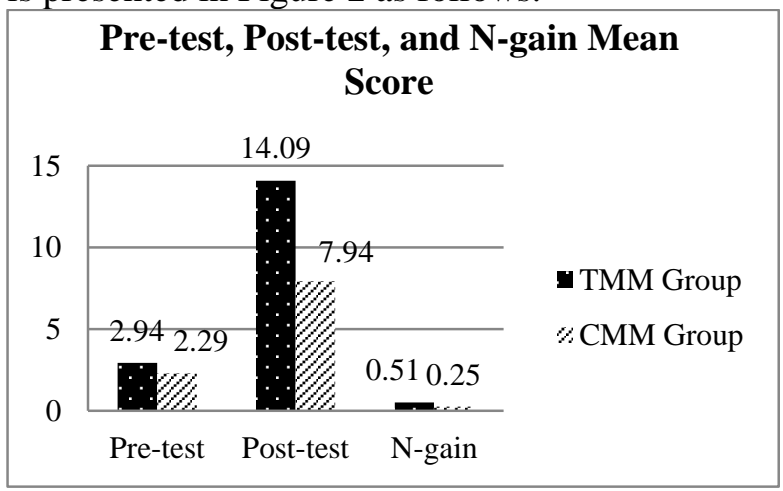

Figure 2. Comparison on the Mean Score of the Pre-Test, the Post-Test, and the N-gain in terms of Mathematical Comprehension Capacity

Prior to the test administration, the requirement that should be met is that the data under the test should come from the normally distributed and homogenous population. In order to identify the normal distribution and the homogeneity, the data are tested in terms of normality by using the SPSS 15 .
Table 2. Results of Test Normality for the Pre-

Test Results on the Mathematical Comprehension

\begin{tabular}{cccc}
\hline \multirow{3}{*}{ Pre-test } & Group & Sig. & Conclusions \\
\hline \multirow{3}{*}{ Post-test } & TMM & 0.222 & $\mathrm{H}_{0}$ is accepted \\
& CMM & 0.580 & $\mathrm{H}_{0}$ is accepted \\
\multirow{3}{*}{ N-gain } & TMM & 0.183 & $\mathrm{H}_{0}$ is accepted \\
& CMM & 0.164 & $\mathrm{H}_{0}$ is accepted \\
& TMM & 0.768 & $\mathrm{H}_{0}$ is accepted \\
& CMM & 0.850 & $\mathrm{H}_{0}$ is accepted \\
\hline
\end{tabular}

From Table 2, the size of Sig. value may be identified for each group. Table 2 displays that the Sig. value $>0.05$ on the pre-test score, the post-test score, and the $\mathrm{N}$-gain score in terms of mathematical comprehension capacity for both classes. Therefore, the researcher might conclude that $\mathrm{H}_{0}$ is accepted and $\mathrm{H}_{1}$ is rejected. The statement implies that the pre-test score data, the post-test score data, and the $\mathrm{N}$-gain score data in terms of mathematical comprehension capacity from both the TMM group and the CMM group come from the normally distributed population.

The homogeneity test is performed in order to view whether the data from the two different groups have similar variance or not. The results of homogeneity test for the pre-test data of the mathematical comprehension capacity from the TMM group and the CMM group can be viewed in Table 3 .

From Table 3, the size of Sig. value on the pre-test score, the post-test score, and the $\mathrm{N}$ gain score may be identified. Table 3 displays that the Sig. value $>0.05$ on the pre-test score, the post-test score, and the $\mathrm{N}$-gain score in terms of mathematical comprehension capacity in both classes. Therefore, the researcher might conclude that $\mathrm{H}_{0}$ is accepted and $\mathrm{H}_{1}$ is rejected. The conclusion implies that the pre-test score data, the post-test score data, and the N-gain score data in both the TMM group and the 
CMM group have similar variance. In other words, the pre-test score, the post-test score, and the $\mathrm{N}$-gain score in terms of mathematical comprehension capacity between both groups are homogenous. The requirement of the test, namely the normal distribution and the homogeneity, has been met. Thereby, the researcher will proceed to the mean equivalence test.

Table 3. Results of Variance Homogeneity on the Mathematical Comprehension Capacity

\begin{tabular}{cllc}
\hline \multirow{2}{*}{ Pre-test } & Group & Sig. & Conclusions \\
& TMM & 0.902 & $\mathrm{H}_{0}$ is accepted \\
\multirow{2}{*}{ Post-test } & TMM & & \\
& CMM & 0.411 & $\mathrm{H}_{0}$ is accepted \\
\multirow{2}{*}{ N-gain } & TMM & 0.575 & $\mathrm{H}_{0}$ is accepted \\
& CMM & & \\
\hline
\end{tabular}

The test of mean equivalence was performed in order to identify whether the data from the two different groups have the similar mean or not or, in other words, whether there were significant differences on the pre-test score of the students' mathematical comprehension between the TMM group and the CMM group. The results of the calculation can be viewed in Table 4.

Based on Table 4, it is apparent that Sig. (2-tailed) value $>0.05$ and as a result the researcher might conclude that there have not been any differences on the pre-test score of the students' mathematical comprehension between the TMM group and the CMM group. Therefore, the researcher might suggest that there have not been any significant differences in terms of preliminary mathematical comprehension between the students in the TMM group and the students in the CMM group.

Table 4. Results from the Test of Mean Equivalence for the Pre-Test Score of Mathematical Comprehension

\begin{tabular}{ccccc}
\hline & Group & $\boldsymbol{t}_{\text {count }}$ & $\begin{array}{c}\text { Sig. } \\
\text { (2-tailed) }\end{array}$ & Conclusions \\
\hline \multirow{2}{*}{ Pre-test } & TMM & 1.718 & 0.091 & $\mathrm{H}_{0}$ is accepted \\
& CMM & & & \\
Post-test & TMM & 6.544 & 0.000 & $\mathrm{H}_{0}$ is rejected \\
& CMM & & & \\
N-gain & TMM & 6.639 & 0.000 & $\mathrm{H}_{0}$ is rejected \\
& CMM & & & \\
\hline
\end{tabular}

From the results of the calculation as well, it is apparent that Sig. (1-tailed) value $<0.05$ and as a result the researcher might conclude that there have been significant differences on the post-test score and the $\mathrm{N}$-gain score between the two groups. Thereby, the researcher might suggest that there have been significant differences between on the final mathematical comprehension between the students in the TMM group and the students in the CMM group. In addition, the researcher might also suggest that the improvement of the students' mathematical comprehension in the TMM group is better than the improvement of the students' mathematical comprehension in the CMM group

Table 5 are the results of pre-test score, post-test score, and $\mathrm{N}$-gain score recapitulation from the students' mathematical communication both from the TMM group and the CMM group.

Table 5. Results from the Test of Mathematical Communication Capacity

\begin{tabular}{crrrrrr}
\hline \multirow{2}{*}{ Statistical Data } & \multicolumn{3}{c}{ TMM Group } & \multicolumn{3}{c}{ CMM Group } \\
\cline { 2 - 7 } & \multicolumn{1}{c}{ Pre-test } & \multicolumn{1}{c}{ Post-test } & \multicolumn{1}{c}{ Pre-test } & Post-test & \multicolumn{1}{c}{ Pre-test } & Post-test \\
\hline N & 32.00 & 32.00 & 32.00 & 31.00 & 31.00 & 31.00 \\
X $_{\text {min }}$ & 0.00 & 8.00 & 0.32 & 0.00 & 1.00 & 0.00 \\
X $\max _{\bar{x}}$ & 6.00 & 21.00 & 0.80 & 6.00 & 21.00 & 0.80 \\
SD & 3.72 & 16.34 & 0.59 & 2.39 & 8.94 & 0.30 \\
$\%$ & 1.84 & 2.99 & 0.13 & 1.48 & 4.73 & 0.16 \\
& 14.88 & 65.36 & 59.40 & 9.56 & 35.76 & 30.00 \\
\hline
\end{tabular}

Note:

Ideal Maximum Score $=25.00$

$\%=$ Mean Percentage toward the Ideal Maximum Score

$\mathrm{N}$-gain Ideal Score $=1.00$

Pre-test and Post-test Mean Scale ranged from 0 - 25, N-gain Mean Scale ranged from 0 - 1, and Percentage Scale ranged from $0-100$.

From Table 5, it is apparent that the mean of the pre-test score from both groups is different; the TMM group has 1.33 points higher mean than the CMM group. In terms of 
percentage, the gap between the two groups is $26.20 \%$. Then, in terms of post-test score the mean of the TMM group is 7.40 points higher than that of the CMM group. Last but not least, in terms of $\mathrm{N}$-gain score the mean of the TMM group is 0.594 while the mean of the CMM group is 0.300 ; the gap between the two groups is 0.290 .The mean comparison on the achievement of the pre-test score, the post-test score, and the $\mathrm{N}$-gain score for the students' mathematical communication is shown in Figure 3.

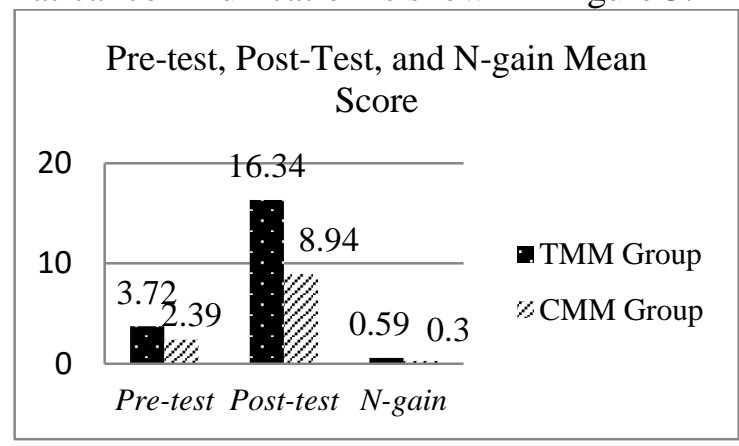

Figure 3. Comparison on the Mean of the PreTest Score, the Post-Test Score, and the N-gain Score for the Mathematical Communication Capacity

The results of the test for the mathematical communication is presented in Table 6.

Table 6. Results of Normality Test for the Pre-

Test Score of Mathematic Communication Capacity

\begin{tabular}{cccc}
\hline & Group & Sig. & Conclusions \\
\hline \multirow{2}{*}{ Pre-test } & TMM & 0.222 & $\mathrm{H}_{0}$ is accepted \\
& CMM & 0.570 & $\mathrm{H}_{0}$ is accepted \\
Post-test & TMM & 0.084 & $\mathrm{H}_{0}$ is accepted \\
& CMM & 0.306 & $\mathrm{H}_{0}$ is accepted \\
N-gain & TMM & 0.122 & $\mathrm{H}_{0}$ is accepted \\
& CMM & 0.910 & $\mathrm{H}_{0}$ is accepted \\
\hline
\end{tabular}

From Table 6, the size of Sig. value in each group might be identified. The above table shows that the Sig. value $>0.05$ on the pre-test score, the post-test score, and the $\mathrm{N}$-gain score of the mathematical communication capacity for both groups. Therefore, the researcher might conclude that $\mathrm{H}_{0}$ is accepted and $\mathrm{H}_{1}$ is rejected. This finding implies that the data from the pretest score, the post-test score, and the $\mathrm{N}$-gain score of the mathematical communication capacity both from the TMM group and the CMM group comes from normally distributed population.

The homogeneity test is also performed on the pre-test data of the mathematical communication capacity in the TMM group and in the CMM group. The results of the test are presented in Table 7 below.

Table 7. Results of Variance Homogeneity Test for the Mathematical Communication Test

\begin{tabular}{cccc}
\hline \multirow{2}{*}{ Pre-test } & Group & Sig. & Conclusions \\
& TMM & \multirow{2}{*}{0.596} & $\mathrm{H}_{0}$ is accepted \\
Post-test & TMM & & \\
& CMM & 0.012 & $\mathrm{H}_{0}$ is rejected \\
\multirow{2}{*}{ N-gain } & TMM & \multirow{2}{*}{0.056} & $\mathrm{H}_{0}$ is accepted \\
\hline
\end{tabular}

Based on the results displayed in Table 7, the researcher might identify the size of Sig. on the pre-test score, the post-test score, and the $\mathrm{N}$ gain score on the mathematical communication capacity and the size of Sig. is 0.05 . This finding implied that $\mathrm{H}_{0}$ was accepted and $\mathrm{H}_{1}$ was rejected. The pre-test score data and the $\mathrm{N}$-gain score data from both the TMM group and the CMM group had the same variance. As a result, the researcher might conclude that the pre-test score, the post-test score, and the $\mathrm{N}$-gain score on the mathematical communication capacity from both groups had been homogenous. However, the researcher found different finding with regards to the post-test data in which the researcher concluded that $\mathrm{H}_{1}$ had been rejected. This rejection implied that the post-test score data from the TMM group and the CMM group had different variance; therefore, the post-test score on the mathematical communication capacity between both groups had not been homogenous.

The prerequisite test, namely the normality test and the homogeneity test, had been met for the pre-test data and the $\mathrm{N}$-gain data but had not been met for the post-test data. As a result, the researcher performed the mean equivalence test by using the t-test for the pretest data and the N-gain data and the $\mathrm{t}$ '-test for the post-test data.

From the pre-test data that had been displayed on Table 8 , the researcher found that the mathematical communication capacity of TMM group had been significantly different than that of CMM group. From the post-test data as well, the researcher found that the mathematical communication capacity of TMM group had been significantly better than that of CMM group. Furthermore, the from the N-gain data, the researcher still found that the mathematical communication capacity of TMM group had 


\section{Jurnal Riset Pendidikan Matematika, 5 (1), 2018 - 38}

Klara Iswara Sukmawati

been significantly improved than that of CMM group.

Table 8. Results of Mean Equivalence Test for the Pre-Test Score on the Mathematical Communication Capacity

\begin{tabular}{|c|c|c|c|c|}
\hline & Group & $t_{\text {count }}$ & $\begin{array}{l}\text { Sig. (2- } \\
\text { tailed) }\end{array}$ & Conclusions \\
\hline $\begin{array}{l}\text { Pre- } \\
\text { test }\end{array}$ & $\begin{array}{l}\text { TMM } \\
\text { CMM }\end{array}$ & 3.167 & 0.002 & $\begin{array}{l}\mathrm{H}_{0} \text { is } \\
\text { rejected }\end{array}$ \\
\hline $\begin{array}{l}\text { Post- } \\
\text { test }\end{array}$ & $\begin{array}{l}\text { TMM } \\
\text { CMM }\end{array}$ & 7.409 & 0.000 & $\begin{array}{l}\mathrm{H}_{0} \text { is } \\
\text { rejected }\end{array}$ \\
\hline $\begin{array}{l}\mathrm{N}- \\
\text { gain }\end{array}$ & $\begin{array}{l}\text { TMM } \\
\text { CMM }\end{array}$ & 7.249 & 0.000 & $\begin{array}{l}\mathrm{H}_{0} \text { is } \\
\text { rejected }\end{array}$ \\
\hline
\end{tabular}

The difference on the improvement was caused by the different learning model that had been implemented in both groups. Specifically, the difference was found in the stages that the researcher performed in delivering the learning materials. In the TMM group, the researcher presented the concrete matters that the students were familiar with in the first place so that the students might imagine these matters (departing from concrete things). The students were provided with the real problems and they performed experiment and manipulation these problems in their group. From this point forward, it is expected that Mathematics will be more meaningful for the students because the students start learning from the matters that are closely related to the prior knowledge that they have mastered. This statement is in line with a theory by David Paul Ausubel (Hudoyo, 1985); Ausubel states that meaningful learning is more important than memorizing learning. Learning will be considered meaningful if the information that the students learn is made in accordance to the cognitive structure that the students have so that the students might associate the new knowledge to the knowledge that they already possess. By means of meaningful learning, the students will have strong concept comprehension. Through this process, it is expected that students will have better comprehension. In addition, with the support of group work, the students might share their ideas in order that they might expand their mastery toward the learning materials. In the TMM group, the students learn from the concrete matters to the abstract matters and their learning stages consist of the enactive stage (the use of display tool), the iconic stage (the use of picture), the symbolic stage (the use of symbol), and the formal stage (the use of abstract materials). After attending all of these stages, the students will be able to associate the concept that they are learning to the concept that they have previously learned.

Different than the sequence in the TMM group, the sequence in the CMM group started from the general concept/definition. The students were provided with the definition about open statement, closed statement, and alike. Then, they were invited to recognize the example of each topic. Afterwards, the students were invited to comprehend the example of the test items that the teacher provided and finally the students were provided with learning exercises and discussions. From these activities, it was apparent that the students directly learned on the formal activities and, as a result, the students had difficulties in associating the new materials to the knowledge that they had already possessed. The students also accepted the learning materials without exploring the display tool that might be grabbed and be operated in order to build a concept comprehension.

The TMM had also been habituated to defining a statement or a concept that they were learning on their own. From what the students had proposed, other people might understand their comprehension. The National Council of Teachers of Mathematics (2000) suggests that communication is a means of sharing ideas and clarifying comprehensions. In addition to writing what the students had understood, they were also invited to state their arguments to their peers so that the students' communication capacity is expected to be better. This statement is in line with the opinion by Sullivan \& Mousley (Ansari, 2013) which states that mathematical communication is not only a matter of stating ideas through writings but also a matter of stating ideas through more expanded activities such as communicating, explaining, describing, listening, clarifying, sharing, composing articles, and reporting what they have learned.

The results of the study were attained from the learning process that the researcher had accomplished and the study was conducted from April $2^{\text {nd }}, 2015$ until April $30^{\text {th }}, 2015$. In the study, the researcher performed two learning processes in two classrooms. One classroom was provided with the Tiered Mathematization Model (TMM) and the other was provided with the Conventional Mathematization Model (CMM). Then, within the study the researcher acted as the teacher for both models. The learning process in the two groups were started 
Klara Iswara Sukmawati

by administering a pre-test prior to the main learning activities. The learning process in each group consisted of six meetings and was implemented by following the lesson plan that had been designed.

In the first meeting, the students were assigned into nine groups and each group consisted of four students. Through the group formation, the researcher expected that the students might discuss and share their ideas so that they might help each other in understanding a concept. The expectation was in line with the suggestion by Vygotsky (Asikin \& Pujiadi, 2011) which stated that social interaction is the most important factor in encouraging/triggering the cognitive development of an individual. After the groups had been formed, the teacher distributed the display tool and the Student's Worksheet -01 to the students. The learning process then begun with the enactive stage in which the students were invited to be involved in the use of the display tool. The display tool was a scale and it was used to introduce the concept of open statement, close statement, variable, and one variable linear regression. In this stage, the students were asked to actively use the scale. The scale was used in order to assist the students in understanding the problems that the teachers had presented in the working sheet.

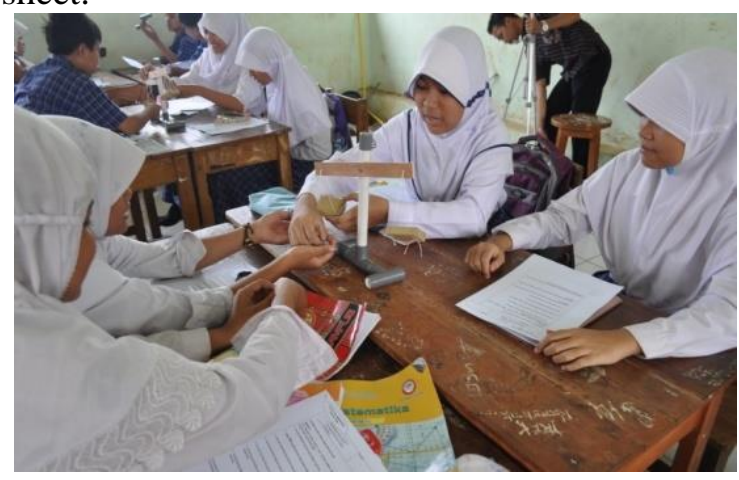

Figure 4. Student's Activities in Using the Display Tool (Scale)

The provided display tool was expected to assist the students to associate and to present the concrete object through mathematical communication in the classroom. The students were also expected to handle and to experience the mathematical communication independently so that they attained experiences in manipulating concrete objects that later would be associated to the mathematical concepts. From these activities, the researcher expected that the learning process became more meaningful for the students.

After the enactive stage, the students were brought to the iconic stage in which the students did not use the display tool but, instead, they had to represent the concrete object into the form of pictures. In this stage, the students were happy and they seemed to be so enthusiastic in drawing the pictures that they passed the time limit. The following is an example of the Student's Worksheet - 01 completions:

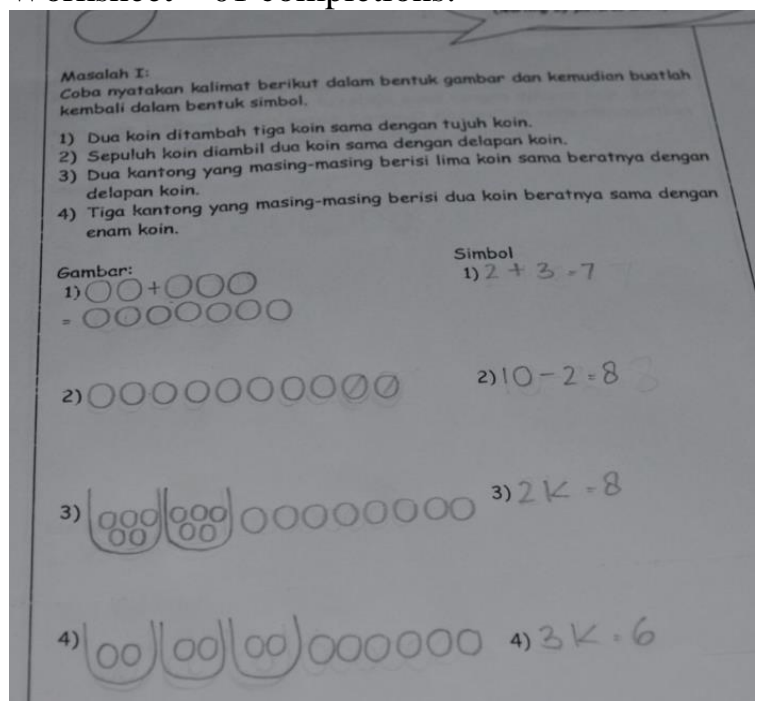

Figure 5. Pictures that the Students Draw

Then, the students were brought to the symbolic stage in which the students started using the general mathematical symbols. In this stage, the students had low self-confidence in using the symbols. The low self-confidence was apparent from the fact that the students still asked the teachers whether the symbols that they had used were correct or not.

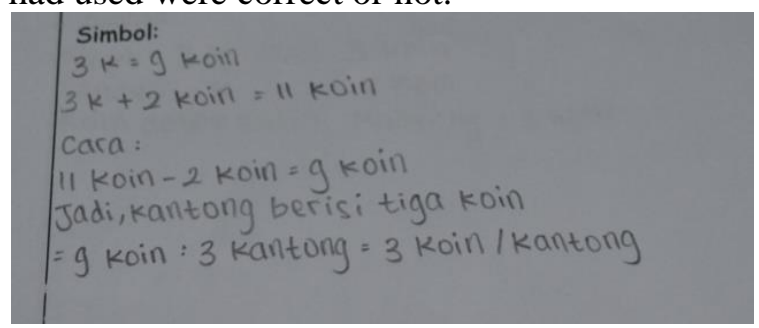

Figure 6. One of the Symbols that the Students Use

The final stage was the formal stage in which the students were invited to define a concept independently through their own language based on their comprehension in the previous stages. Afterwards, the students were provided with the exercises from both the textbook and the Student's Worksheet - 01 . 


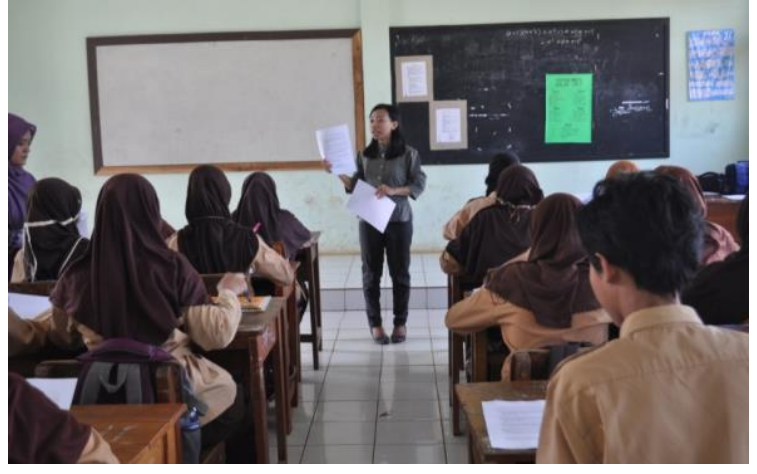

Figure 7. Formal Stage Activities are Focused on the Teacher

In overall, the students learning activities had been well performed. The students were quite assisted with the presence of the worksheet that had been distributed. However, there were many students who had been slow in understanding the intention of the narrative text items that the researcher provided. On the other hand, the learning activities in the CMM group that made use of the conventional learning process were performed by distributing centrally the learning materials and performing question and answer session with the researcher. Then, the activities were continued by providing examples and administering exercise test items. All of these activities were performed under the teacher's direction.

In general, the learning activities might be implemented well and smoothly. However, the researcher found several obstacles. First, the students were not accustomed to the narrative test items and, as a result, they were unwilling on the very first place before they tried to comprehend and complete the narrative test items. Second, the students' capacity of performing calculative operation in both groups that were still low often hindered the learning process that the researcher performed because the researcher should re-explain the learning materials about the operation of integer and fraction. Third, the researcher had delays in conducting the study and consequently the researcher seemed to have not provided the sufficient exercise in the form of narrative text items to the students. In both groups, some students had low learning motivation and these students started making jokes to their peers who would like to learn. Fourth, the classroom condition was not comfortable for the students to learn; the temperature within the classroom was so hot that the students were unwilling to learn Mathematics especially in the afternoon.
Fifth, the researcher still had difficulties in managing the classroom under the existing situations. The researcher should train herself more in dealing with the motivational gap among the students. Not to mention, the researcher still had to be strict in dealing with the students who were sometimes rebellious.

\section{CONCLUSIONS}

Based on the results of the study that had been conducted, the researcher found that the improvement of junior high school students' mathematical comprehension in the Tiered Mathematization Model group is significantly better than that of junior high school students' mathematical comprehension in the Conventional Mathematization Model. The improvement that has occurred in the Tiered Mathematization Model group belongs to the "Moderate" category, while the improvement that has occurred in the Conventional Mathe-matization Model group belongs to the "Low" category.

The implementation of Tiered Mathematization Model that the researcher performed has not shown the optimal results due to the several obstacles that the researcher should deal with. As a matter of follow up, the researcher would like to provide several suggestions for the future studies. Prior to conducting the study, the future researchers are expected to inspect first the required capacity that the students should master so that the future researchers might consider the better management of the study. The implementation of Tiered Mathematization Model demands quite a long period of time; therefore, the future researchers should pay attention to the time management. Specifically, on the formal stage the future researchers should allocate more time to the students so that better results that meet the future researchers' expectation can be gathered.

\section{REFERENCES}

Anggraeni, D. (2013). Meningkatkan kemampuan pemahaman dan komunikasi matematik siswa smk melalui pendekatan kontekstual dan strategi formulate-sharelisten-create (FSLC). Infinity Journal, 2(1), https://doi.org/10.22460/infinity.v2i1.20

Ansari, B. I. (2013). Menumbuhkembangkan kemampuan pemahaman dan kemampuan komunikasi siswa melalui strategi thinktalk-write: Studi eksperimen pada siswa kelas 1 SMUN di Kota Bandung. 
Universitas Pendidikan Indonesia.

Asikin, M., \& Pujiadi, P. (2011). Pengaruh model pembelajaran matematika creative problem solving (CPS) berbantuan CD interaktif terhadap kemampuan pemecahan masalah pada siswa SMA kelas X. Lembaran Ilmu Kependidikan, 37(1). Retrieved from https://journal.unnes.ac.id/nju/index.php/L $\mathrm{IK} /$ article/view/514

Baroody, A. J., \& Coslick, R. T. (1993). Problem solving, reasoning, and communicating, $K-8$ : helping children think mathematically. New York, NY: Merrill.

Einstein, A. (n.d.). If you can't explain it simply, you don't understand it well enough. Retrieved May 23, 2018, from https://www.brainyquote.com/quotes/alber t_einstein_383803

Gravemeijer, K. P. E. (1994). Developing realistic mathematics education: Ontwikkelen van Realistisch Reken/wiskundeonderwijs. Utrecht: CD[beta] Press.

Hendriana, H. (2012). Pembelajaran matematika humanis dengan metaphorical thinking untuk meningkatkan kepercayaan diri siswa. Infinity Journal, 1(1), 90. https://doi.org/10.22460/infinity.v1i1.9

Herawati, O. D. P., Siroj, R., \& Basir, D. (2010). Pengaruh pembelajaran problem posing terhadap kemampuan pemahaman konsep matematika siswa kelas XI IPA SMA Negeri 6 Palembang. Jurnal Pendidikan Matematika, 4(1), 70-80. Retrieved from https://ejournal.unsri.ac.id/index.php/jpm/ article/view/312/75

Hudoyo, H. (1985). Teori belajar dalam proses belajar-mengajar matematika. Jakarta: Depdikbud.

Idris, N. (2009). Enhancing students' understanding in calculus trough writing. IEJME-Mathematics Education, 4(1), 3655. Retrieved from http://www.iejme.com/makale/323

National Council of Teachers of Mathematics. (2000). Principles and standards for school mathematics. Reston. VA: National Council of Teachers of Mathematics.

Nelissen, J. M. C. (1993). Learning and thought processes in realistics mathematics instruction. Utrecht: James Nicholas Publisher.

Ontario Ministry of Education. (2005). The Ontario curriculum, grades 1 to 8 : Mathematics. Toronto, ON: Queen's Printer for Ontario.

Pugalee, D. (2001). Spotlight on the standards: using communication to develop students' mathematical literacy. Mathematics Teaching in the Middle School, 6(5). Retrieved from https://www.nctm.org/Publications/mathe matics-teaching-in-middleschool/2001/Vol6/Issue5/Spotlight-on-theStandards_-Using-Communication-toDevelop-Students_-MathematicalLiteracy/

Rudhito, M. A. (2005). Perancangan dan pelaksanaan model pembelajaran persamaan kuadrat untuk kelas X SMA dengan pendekatan matematisasi berjenjang. Widya Dharma, 16(1), 67-76. Retrieved from http://ejournal.usd.ac.id/index.php/WidyaDharma

Subagiana, S. (2009). Peningkatan kemampuan pemahaman dan komunikasi matematis siswa SMP menggunakan model pembelajaran kooperatif tipe teams assisted individualization (TAI) dengan pendekatan kontekstual. Universitas Pendidikan Indonesia.

Sukmawati, K. I. (2010). Penerapan matematisasi berjenjang pada materi perkalian aljabar dan pemfaktoran sebagai upaya meningkatkan hasil belajar dan minat siswa di kelas VIIB SMP Pangudi Luhur Yogyakarta tahun ajaran 2011/2012. Universitas Sanata Dharma.

Sukmawati, K. I. (2014). Penerapan model matematisasi berjenjang pada materi penjumlahan dan pengurangan bilangan bulat. In Prosiding Seminar Pendidikan Matematika Universitas Ahmad Dahlan Yogyakarta. Yogyakarta: Universitas Ahmad Dahlan Yogyakarta.

Susento, S. (2007). Model pembelajaran matematisasi berjenjang. Yogyakarta.

Susento, S., \& Rudhito, M. A. (2008). Model pembelajaran matematisasi berjenjang: Integrasi pendekatan-pendekatan konstruktivistik, kontekstual dan kolaboratif. In Prosiding Seminar Nasional Sain dan Pendidikan Sain, 
Jurnal Riset Pendidikan Matematika, 5 (1), 2018 - 42

Klara Iswara Sukmawati

"Pembelajaran Sain yang Menarik dan Menantang" FSM UKSW. Salatiga: Universitas Kristen Setya Wacana.

Treffers, A. (1993). Wiskobas and Freudenthal realistic mathematics education. Educational Studies in Mathematics, 25(1-2), 89-108. https://doi.org/10.1007/BF01274104

Winayawati, L., Waluya, S. B., \& Junaedi, I.
(2012). Implementasi model pembelajaran kooperatif dengan strategi think-talk-write terhadap kemampuan menulis rangkuman dan pemahaman matematis materi integral. Unnes Journal of Mathematics Education Research, 1(1), 65-71. Retrieved from https://journal.unnes.ac.id/sju/index.php/uj mer/article/view/36 